\title{
NON-AGENDA
}

With the view of causing an increase to take place in the mass of national wealth, or with a view to increase of the means either of subsistence or enjoyment, without some special reason, the general rule is, that nothing ought to be done or attempted by government. The motto, or watchword of government, on these occasions, ought to be - Be quiet. . . Whatever measures, therefore, cannot be justified as exceptions to that rule, may be considered as nous-agenda on the part of government.

\section{The Economic and Social Impact of Tax-Deductible Household Help}

\author{
Garry M. White
}

$\mathrm{T}$

TRADE liberalisation, technological change and greater competitive pressure in domestic markets are having major positive impacts on the wealth of the Australian community. But these benefits may well be distributed disproportionately in favour of the better educated and skilled. The government's response has been increasingly to use the tax and welfare systems to redistribute incomes (the 'social wage'). There have also been major programs to improve the skills and employability of the long-term unemployed. But job opportunities for the poorly educated and unskilled may well continue to decline.

International specialisation will send offshore an increasing number of low- skill jobs in the manufacturing and service sectors. Lightly skilled activities will remain in demand where there is little opportunity for foreign competition (leaving aside the possibility of importing labour for these tasks). These jobs will include the provision of services to the relatively well educated and skilled. Some of these services, such as the use of restaurants or prepared foods, will be provided outside the home. But the demand for household duties to be provided by non-family members will increase. The demand for quality time with children or for recreation for those on high incomes will further increase the demand for help with home duties like child minding and transportation, cleaning, washing, ironing, food preparation, purchasing of household supplies, gardening, lawn mowing and home maintenance. The 
pressures on home carers for those with disabilities through accident, genetic abnormality or age are also increasing, providing a further demand for home help.

At the same time a significant proportion of the well qualified and skilled population (mainly women) is discouraged from working by the expense of purchasing household support from after-tax income. The community has invested heavily in these individuals in education and work experience. In addition, the average hours of work for those employed has been increasing while the rate of unemployment has crept up over time, increasing the demand for household services. For example, in August 1983 the average number of hours worked by a male in fulltime employment was 41 hours a week. Latest figures show that a male in full-time employment is now working an average of 44 hours a week (ABS, various). As a result, many people are less able to supply their home services for themselves while another large group has little else to do.

A further social development is the aging of the population. Compulsory retirement age and increasing longevity create both a pool of productive and skilled people from the early part of the traditional retirement period and a greater number of aged persons requiring support later in life.

These economic trends and pressures are unlikely to be reversed, and will probably intensify over the coming decades.

\section{A Policy Option: Tax-Deductible Home Help}

The economic issue is how best to utilise the nation's resources to create wealth. The social issue is how to provide the opportunity for meaningful and satisfying lives for all Australians. It is also important that desirable or inevitable economic changes are not accompanied by avoidable social dislocation.

One option is to make the cost of home help tax deductible. This would have the effect of integrating home and traditional economic activity. The object would be to remove an economic distortion that currently stifles economic activity and has the potential to create a community split between the winners and losers from recent and prospective economic pressures.

The proposal might be implemented in the following way:

- expenditure by individuals on home support services to themselves or their dependants would be tax deductible;

- where externally employed household members shared support services, they would share equally in the tax deduction for home help; and

- tax deductibility for home help expenditure would require evidence that the services had been provided at arms' length and that home helpers were within the tax system.

\section{Economic Impact}

Australian households are already purcliasing a modest amount of household help. But the current level of expenditure on these services suggests that there is a considerable scope for the purchase of much greater levels of household services. The 
ABS (1990:10-11) indicates that the average household spends a little over $\$ 4$ a week on the range of household services being considered here. More than $\$ 9$ on average was spent by the highest quintile of income earners.

The impact of the proposal can be demonstrated by an example that, while illustrating some broad relationships and magnitudes within this brief exposition, is not intended to be indicative of the economy-wide impact of the proposed policy. The key impacts of interest here are those on national economic output (actual and as usually measured), on household income and on tax revenue.

The household used for the example includes two well-qualified adults, one of whom works a typical professional week of 50 hours and also contributes 12 hours of home duties. The earnings of the first adult might be the equivalent of $\$ 30$ per hour worked. The other adult is currently working part-time for 20 hours per week earning $\$ 20$ per hour and also contributes 52 hours of home duties. No outside resources are used to provide home help. The second adult's earnings are lower because part-time work is relatively less well paid and careers are disrupted by taking responsibility for home duties such as care of children or invalid relatives.

The household has an initial gross income of $\$ 1,900$ per week. Under current tax rates the household pays total tax of $\$ 584$, leaving a net income of $\$ 1,316$ (the Medicare Levy is ignored in this example). Australia's national accounts would measure these adults as contributing $\$ 1,900$ to the nation's income. However, if their contribution to national income included home duties (valued at say $\$ 12$ per hour) then their total economic contribution would be $\$ 2,668$.

Now consider an alternative scenario under which the second adult took up a preference to work in a full-time ( 40 hour per week) position at $\$ 25$ per hour and replace 25 hours of home duties with an additional 20 hours of employment plus an additional five hours travelling time and $\$ 25$ in travel costs. Under current tax arrangements and rates, the second adult would receive a weekly income of $\$ 1,000$ per week, and the household gross income rises to $\$ 2,500$ per week. However, $\$ 300-50$ per cent of the additional gross income - would now be spent on outside home help. And after paying additional tax of $\$ 230$ and $\$ 25$ in travel costs, the second adult would have only an additional $\$ 4.5$, or a net of $\$ 2.25$ per additional hour worked, as a reward for an additional $\$ 600$ contribution to national economic activity.

The decision of the second adult to seek additional employment as outlined above increases measured national income to $\$ 2,800$ from $\$ 1,900$ if the value of unpaid household help is excluded from national income. If the value of unpaid household help is included, the increase in national income is less, with a rise to $\$ 3,268$ from $\$ 2,668$. An increase in national income in our example of between 47 per cent and 22 per cent results in an increase in household disposable income of only 3.7 per cent. An exceptionally high marginal tax rate resulting from the current tax treatment of household help is evident in this example.

The economic incentives resulting from the tax deductibility of home help are substantial. Taking the previous example, if these services were tax deductible, net disposable household income (after tax, additional travel costs and household help) 
would increase by $\$ 180$ rather than the $\$ 45$ per week previously achieved. The implied marginal 'tax' rate (after PAYE tax, external costs of home help and additional travel costs) in relation to the extra $\$ 600$ per week earned by the second adult falls from 92.5 per cent to 76 per cent.

\section{Economic Efficiency}

The foregoing example shows how the tax system discourages the use of existing human capital by the artificial separation of home duties and traditional paid work. The loss of economic activity results from a reduction in the specialisation of labour as well-qualified persons are encouraged to devote too high a proportion of their time to household duties. At the same time, employment opportunities are reduced for those persons who have a comparative advantage in performing home duties.

It should be noted that not all home duties are easily provided by external suppliers. While some mundane duties (it is asserted that certain tasks such as cleaning and ironing are regarded as mundane by many Australians) are readily supplied by external suppliers, other services are less readily provided by external suppliers. Activities including interaction with children and gardening are often seen as providing non-pecumiary benefits which would militate against the substitution of outside suppliers for supply from within the household. The substitutability of intenial rather than external provision of household help will therefore vary greatly between households and, for particular services, within each household.

Of interest to the government is the impact on measured levels of economic activity. To gain tax deductibility it would be necessary for providers of household services to be taxed. These providers would also, therefore, have their economic activity measured as part of national income. Govenments could expect economic growth to appear to increase for a period as households and household-help providers adapted to the new tax regime. This increase would be additional to the 'real' increase in national income resulting from the proposed policy.

The argument for tax-deductible home help largely relates to the issue of whether a fuller measure of the economic costs of engaging in the workforce should be recognised within the tax system. There may be a trade-off between the benefits of increased efficiency within the labour market and the impact of higher tax rates if the policy resulted in lower tax revenue. However, it is not clear that overall tax revenue would fall following the introduction of the proposed new category of tax deduction.

\section{Tax Revenue and Government Expenditure}

The impact on tax revenue of making home help tax deductible is ambiguous. Tax revenue would fall in situations where current use of home help remained at similar levels. This is because the marginal tax rates of those employing household help are generally higher than those delivering household services. As well, much home help is provided on a cash basis, with a subsequent loss of tax revenue to the gov- 
ernment. Tax revenue would increase by the extent to which home-service providers were brought into the tax system by the proposed policy. Better compliance in relation to social security payments might also be achieved. Tax revenue would be increased, and social security payments would be reduced, to the extent that the proposed policy created additional employment.

In the above example, the tax revenue increases if home help is made tax deductible. For the houseloold, income tax is $\$ 584$ in the initial situation, notionally $\$ 814$ after expanded work hours without tax deductibility for home help, and $\$ 677$ after tax deductibility. In addition, tax is paid by the home help provider.

Household help could be tax deductible at the marginal rates of tax of the employers; alternatively, a tax rebate could be made available at a fixed tax rate. As the objective of the policy is very much to improve economic efficiency (by encouraging those with the greatest earning capacity to work more hours in their most productive activity), tax deductibility is preferable to a tax rebate.

\section{Social Impact}

The social impact of making household help tax deductible would depend on the extent to which Australians took advantage of the opportunity. The potential positive social impacts would include:

- offering a wider range of employment opportunities to those currently facing reduced employment opportunities because of factors like structural adjustment, lack of skills or employer bias against mature workers ;

- encouraging a mixing of social groups and thereby demonstrating the benefits of education and vocational skills;

- providing parents with high professional time demands with increased quality time with children or the opportunity to pursue other leisure activities;

- providing opportunities for professionally trained women to pursue a more satisfying career at higher levels than might otherwise be possible;

- allowing women from lower-income families to gain additional income through work which by its nature often allows flexibility in working hours to fit in with their household responsibilities; and

- providing those caring for invalids with the opportunity to afford to mix external employment with caring and thereby achieving a more satisfying lifestyle.

Are there any potential social disadvantages? It might be argued that the proposed policy might see a return to social stratification between servant classes and those with households. Whether this style of stratification is likely to occur within the Australian community is debatable. It could also be argued that children may be disadvantaged if mothers are encouraged to become more involved in the workforce. This latter argument is the subject of an unresolved debate within another discipline. 


\section{Conclusion}

The idea of tax deductibility for household help is put forward as a means of improving the economic efficiency of the Australian economy. While the foregoing exercise represents only a first assessment of the proposal, it appears to lead to a higher national income and better use of the human capital that the community has invested in over past years. It also has the capacity to solve part of the problem resulting from the disparate impact of structural adjustment on certain groups within the labour market. The proposal would provide greatest benefit to women and has the potential to lead to other social benefits.

\section{Summary of household simulation}

\begin{tabular}{|l|c|c|c|}
\hline & Scenario 1 & Scenario 2 & Scenario 3 \\
\hline Household total paid work hours & 70 & 90 & 90 \\
\hline $\begin{array}{l}\text { Household total unpaid domestic work } \\
\text { hours }\end{array}$ & 64 & 44 & 44 \\
\hline Household total paid domestic work hours & 0 & 20 & 20 \\
\hline Household total gross income per week (\$) & 1,900 & 2,500 & 2,500 \\
\hline Household total tax per week (\$) & 584 & 813 & 677 \\
\hline Household total net income per week (\$) & 1,316 & $1,361^{\star}$ & $1,498^{\star}$ \\
\hline $\begin{array}{l}\text { Contribution to national Income WITHOUT } \\
\text { unpaid household work (\$) }\end{array}$ & 1,900 & 2,800 & 2,800 \\
\hline $\begin{array}{l}\text { Contribution to national income WITH un- } \\
\text { paid household work (\$) }\end{array}$ & 2,668 & 3,268 & 3,268 \\
\hline
\end{tabular}

"Less tax, additional travelling expenses and cost of household help

\section{Scenario 1}

- Principal income eamer $50 \mathrm{hpw}$ paid work and $12 \mathrm{hpw}$ ir unpaid domestic work.

- Secondary income earner $20 \mathrm{hpw}$ in paid work and $52 \mathrm{hpw}$ in unpaid domestic work.

\section{Scenario 2}

- Principal income eamer $50 \mathrm{hpw}$ paid work and $12 \mathrm{hpw}$ in unpaid domestic work.

- Secondary income eamer $40 \mathrm{hpw}$ in paid work and $32 \mathrm{hpw}$ in unpaid domestic work.

- Third party employed for $20 \mathrm{hpw}$ in paid household work.

- No tax exemption.

\section{Scenario 3}

- Principal income eamer $50 \mathrm{hpw}$ paid work and 12 hpw in unpaid domestic work.

- Secondary income eamer $\mathbf{4 0} \mathrm{hpw}$ in paid work and $\mathbf{3 2} \mathrm{hpw}$ in unpaid domestic work.

- Third party employed for $20 \mathrm{hpw}$ in paid household work.

- Tax exemption.

\section{References}

Australian Bureau of Statistics (ABS) (various), The Labour Force Australia, AGPS, Canberra (Cat. No. 6203.0).

- (1990), Household Expenditure Survey Australia: Detailed Expenditure Items, AGPS, Canberra (Cat. No. 6535.0). 